\title{
The analysis of operating leverage effects based on EBIT changes
}

\author{
Bayi Guan, Jing Zhang, Zhanli Shang \\ Yantai Nanshan University, Yantai, China
}

\begin{abstract}
The profit change rate is the core of performance evaluation in enterprise management, but the key point of the profit changes should be the use of operating leverage. Enterprise operators use operating leverage to increase the EBIT of their enterprise frequently, so operating leverage become the main way to influence EBIT by management methods. With factor analysis and application cases method, we will analyze impact factors of operating leverage coefficient. From the point of EBIT changes, to provide reference for increase profit by operating leverage and avoid risk for Enterprise operators.

Index Terms - EBIT; change; rate of change; operating leverage; effect

With the background of performance evaluation which operating managers increase profit by use operating leverage effect, the effective application of operating leverage becoming the core issue of business decision. How to increase the EBIT by volume and profit leverage effect changes has become the focus of enterprise competition. Operators will always find a successful way of doing business, increase the EBIT of its enterprise by operating leverage. In practical work, the utilizing of operating leverage accompany with a certain amount of risk. It is not only has positive effect, but also has negative effect if made a mistake in judgment. Through the analysis in effect of operating leverage and its coefficient, to seek methods that increase EBIT and avoid negative effect efficiently that operating leverage might bring.
\end{abstract}

\section{The Factors that Influence Operating Leverage Effect}

The existence of fixed costs affect the change of EBIT and sales volume, the result of the impact is that the rate of change in EBIT is greater than the rate of change in sales volume. Using operating leverage, the operator improves the enterprise's profitability and capability of risk-taking. From the perspective of management, there are three factors influencing EBIT, firstly, fixed cost, which total will not change, but fixed cost per unit will change with changes of sales volume. Secondly, variable cost, which has direct proportion with sales volume. Thirdly, the factor should be contribution margin, which reflect dependencies among unit price, unit variable costs and sales volume. These three determine the amount of EBIT, which measure operating leverage coefficient with the action of the rate of change in EBIT and sales volume, finally operating performance and risk will be present through data.

\section{A. Fixed cost}

Fixed cost usually means the cost that the total doesn't change with sales volume. For example, the fixed assets depreciation is amortized through the straight-line method, the same yearly. Or the fixed Assets depreciation is accrued through accelerated depreciation methods, which doesn't change with sales volume to influence total, and with the annual pace accelerating, the same monthly. But fixed cost will change with sales volume to influence unit fixed cost, and lead to EBIT changing.

\section{B. Variable cost}

Variable cost is the cost that changes with produce and sales volume in positive direction. For example, direct materials and direct labor in cost accounting, which change with produce volume, of course, they also will change with sales volume. Variable cost strongly reflects with produce and sales volume, so operators will remarkably concerned about the change of produce and sales volume. They are correlated in a positive direction.

\section{Contribution margin}

Contribution margin is an indicator which is composite relatively, or, a balance point index. It is sales revenues of product or commodity minus variable cost, equal to breakeven point. The bottom line of price strategy is contribution margin, it is a profit targets. Through equation $M=p x-b x=$ ( $\mathrm{p}-\mathrm{b}) \mathrm{x}=\mathrm{m} \mathrm{x}$, We can reveals the law more clearly. $\mathrm{M}$ is contribution margin, $\mathrm{p}$ is unit product price, $\mathrm{b}$ is unit variable cost, $\mathrm{x}$ is production and consumption by product and $\mathrm{m}$ is unit contribution margin. Thus, we can see that when we don't consider fixed cost, the effect of contribution margin lies on the interactions of price, variable cost, production and consumption by product. Contribution margin is proportional to unit contribution margin, production and consumption.

Through the equation $E B I T=p x-b x-a$, we can get the conclusion that three factors influence EBIT should be fixed cost, variable cost and contribution margin.

\section{Analysis in Factors that Influence Operating Leverage Effect}

$$
\begin{aligned}
& \text { DOL }=E B I T \text { variation/sales volume variation } \\
& =\left(\Delta \mathrm{EBIT} \mathrm{EBIT}_{0}\right) /\left(\Delta \mathrm{x} / \mathrm{x}_{0}\right) \\
& =\left[\left(\mathrm{EBIT}_{1}-\mathrm{EBIT}_{0}\right) / \mathrm{EBIT}_{0}\right] \times\left[\mathrm{x}_{0} /\left(\mathrm{x}_{1}-\mathrm{x}_{0}\right)\right] \\
& =\left\{\left[\mathrm{px}_{1}-\mathrm{bx}_{1}-\mathrm{a}-\left(\mathrm{px}_{0}-\mathrm{bx}_{0}-\mathrm{a}\right)\right] / \mathrm{EBIT}_{0}\right\} \times\left[\mathrm{x}_{0} /\left(\mathrm{x}_{1}-\mathrm{x}_{0}\right)\right] \\
& =(\mathrm{p}-\mathrm{b}) \mathrm{x}_{0} / \mathrm{EBIT}_{0}=(\mathrm{p}-\mathrm{b}) \mathrm{x}_{0} /\left[(\mathrm{p}-\mathrm{b}) \mathrm{x}_{0}-\mathrm{a}\right] \\
& \text { From the last step, the DOL equation can be simplified }
\end{aligned}
$$
as:

DOL =base contribution margin/ base EBIT

Note: In the equation, DOL is operating leverage coefficient; EBIT0 is earnings before interest and tax before 
changes or base earnings before interest and tax; $\triangle$ EBIT is changed amount of earnings before interest and tax; EBIT1 is earnings before interest and tax after changes or current earnings before interest and tax. $\mathrm{x} 0$ is production volume (or sales volume) before changes, or base production volume (or sales volume); $x 1$ is production volume (or sales volume) after changes, or current production volume (or sales volume); $\Delta \mathrm{X}$ is changed amount of production volume (or sales volume), $p$ is unit price, $b$ is unit variable cost, $a$ is fixed cost.

Application example: there are unit price, variable cost, unit contribution margin, sales volume, contribution margin, fixed cost, EBIT of Hanhai Co.(see table below). According to the data in the table, calculate operating leverage coefficient of Hanhai Co. in different dimension, compare and analyze calculation method and influencing factor.

Table 1. Hanhai Co.’s profit

\begin{tabular}{|l|l|l|}
\hline Items & First year & Unit : Yuan \\
\hline Unit price & 400 & 400 \\
\hline Unit variable cost & 240 & 240 \\
\hline Unit contribution margin & 160 & 160 \\
\hline Sales volume & 20000 & 40000 \\
\hline Contribution margin & 1600000 & 3200000 \\
\hline Fixed cost & 800000 & 800000 \\
\hline EBIT & 800000 & 2400000 \\
\hline
\end{tabular}

From the above data analysis, the second year $\mathrm{DOL}_{2}=(2$ $400000-800000$ ) /800 000]/[(40 000-20 000)/20 000]=2, in other words, sales volume doubled make contribution margin doubled in the second year when other data are stable. EBIT changed in positive direction.

Thus, we use the simplified equation of DOL to verified and calculated DOL in the second year by base data. The second year $\mathrm{DOL}_{2}=$ base contribution margin/base $\mathrm{EBIT}=1$ $600000 / 800000=2$.

From the above results we can know that sales volume increased by $100 \%$ than the original from the first year to the next year, contribution margin was $200 \%$, earnings before interest and tax increases [ ( ( $2400 \quad 000-800 \quad 000$ ) /800 $000]=200 \%$. Therefore, using the amplification effect of operating leverage, under the condition of possible enterprise will getting more excess profit through proper increase produce and sales volume in the practical work, but once the sales were sluggish, profits will drop sharply, the stock will soar, causes the firm's capital pressure and the inventory increased, causing the financial pressure.

From the influencing factors, decomposition formula and application example of operating leverage, ultimately the factors which influence operating leverage coefficient is unit price, unit variable cost, unit fixed cost, sales volume. When other factors fixed, multiple of sales changes is multiple of increased or decreased earnings before interest and tax, they are changed in directly proportional direction.

\section{Business Related Financial Leverage}

Although the main aspect is operating leverage on the impact of changes in earnings before interest and tax, we should pay proper attention to financial leverage because it also influences changes in earnings before interest and tax. Financial leverage is which by debt to get more profits for the enterprise or bring more risks, it lead profit to change in leverage effect, affect leverage change benefit of earnings before interest and tax and equity of common shareholders.

$\mathrm{DFL}=$ Profit rate of common stock per share /earnings before interest and tax rate of change

$=(\triangle \mathrm{EPS} / \mathrm{EPS} 0) /(\triangle \mathrm{EBIT} / \mathrm{EBIT} 0)$

$=[($ EPS1-EPS0 $) /$ EPS0 $] /[($ EBIT1-EBIT0 $) /$ EBIT0 $]$

$=\{[($ EBIT $1-\mathrm{I}) \times(1-\mathrm{t})-\mathrm{E}] / \mathrm{n}-[($ EBIT0-I $) \times(1-\mathrm{t})-\mathrm{E}] / \mathrm{n}\} \div$

$\{[($ EBIT0-I $) \times(1-\mathrm{t})-\mathrm{E}] / \mathrm{n}\} \quad \div[($ EBIT1-EBIT0 $) /$ EBIT0 $]$

$=$ EBIT0/[EBIT0-I-E/(1-t)]

When $\mathrm{E}=0$, that is, with the absence of preferred stock dividends, DFL=EBIT0/ $($ EBIT0-I $)=$ base EBIT/ base PBT.

When base earnings before interest and tax rate fixed, the leverage greater, the greater the degrees of financial leverage the greater changes in earnings before interest and tax rate. If changes in earnings before interest and tax rate were in positive direction, the share equity for shareholders will increase dramatically, shareholders will be satisfied .Otherwise, reduce conversely, the shareholders dissatisfied.

\section{A. Tax effect of financial leverage}

Debt incurred interest payments are financial expenses, which can be in pre-income tax before, with the tax effect. For enterprise which production and profit is relatively stable, use of financial leverage by the pattern of debt will increase in earnings before interest and tax, bring more surplus for common shareholders. For enterprise whose production and profit is not stable, use of financial leverage by borrowing pattern in earnings before interest and tax will be reduced, leading to common shareholders' surplus fallen sharply, causing shareholders reduce the number of cases, causes financial risk in the enterprise.

\section{B. Financial leverage effect of shareholder's equity}

The use of financial leverage is to solve the problem of funds, belong to the nature of debt financing. From the point of view of asset-liability ratio, it is the profitability that the enterprise use external funds; from the point of view of the operator, is ability to return to the shareholders use debt financing. So, at the same time in the use of financial leverage, must ensure that the changes in earnings before interest and tax rate is on the rise, to be able to produce positive leverage effect to shareholders' equity, operator's performance can be recognized by majority shareholders, otherwise may let the operator out early.

\section{Financial leverage effect of bankruptcy risk}

According to international practice, the most reasonable rate of the assets and liabilities in enterprises is controlled between $40 \%$ and $60 \%$. It can guarantee utilization of 
liabilities to be maximized; also can let enterprise be away from bankruptcy risk. But, in the real work, if operator excessive use of financial leverage for debt, meanwhile earnings before interest and tax decline, can lead enterprise' net profit to loss, and have to face the resulting risk of bankruptcy.

In conclusion, the use of financial leverage, which is based on stable or positive changes in earnings before interest and tax rate on the basis of operating leverage under the premise of effective use, can obtain satisfied effect.

\section{Operating Leverage Risk and Control}

\section{A. Operating leverage risk}

The purpose of using operate leverage is increasing sales volume, enlarge the contribution margin, expand total business volume, and achieve the promotion of earnings before interest and tax. Total sales promotion will reduce the expend of unit variable cost and fixed cost, the goal of using is make variable cost and fixed cost which corresponding to the unit business volume decreased to increase EBIT. Its risk is the uncertainty of market demand and cost factors, namely the uncertainty risk of the price and the cost. When sales changes, operating leverage is just enlarged or reduced the intensity of profit changes. The larger the coefficient, more intense the variation will be.

\section{B. Risk control of operating leverage}

According to the influence factor of operate leverage coefficient, there are three ways to control and reduce operating risk, firstly analyze market expect, forecast product life cycle, increase sales volume efficiently, reduce the inventory stock. Secondly lower unit variable cost on the basis of sales volume expansion, to increase the competitiveness of products in the market. Thirdly use business performance of produce and sales volume effectively, reduce the share of fixed coats in unit product costs.

\section{Conclusion}

Using operate leverage is based on product sales and produce volume changes, marginal contribution, and positive EBIT changes. Production rise caused the enterprise earnings before interest and tax is multiple changes. The starting point of operating leverage is conducted business target standing on the position of company operators.

\section{References}

[1] Zhang, X.L. Critical reflection of financial management conceptual framework. 2013. Finance and accounting monthly.

[2] Li, L. 2013. Financial statement analysis. Beijing: China Posts \& Telecom Press. 